\title{
INCUBATION AND HATCHING PERFORMANCE OF OSTRICH EGGS DEPENDING ON THEIR STORAGE TIME
}

\author{
Lumturi Sena, Sabah Sena \\ Department of Animal Production, Agricultural University of Tirana, Albania \\ lumturisena@yahoo.com
}

\begin{abstract}
The study was done in the ostrich farm in Patos - Albania. One egg setting was monitored, through dividing the eggs into three groups according to their age, as following: 20-30 days old, 10-20 days old and 1-10 days old. All the 197 eggs were marked according to their age of storage. During the hatching process, the respective parameters, such as: the total eggs set, fecundity, embryonic mortality, weight loss, were followed, recorded and monitored. Related to all these parameters, the appropriate incubation regime was selected. The average weight loss of all the eggs, no matter of their age, resulted to be $5.3 \%$, or $0.5 \%$ more than the standard. The reason of the high embryonic mortality (40.7\%) relates mainly with the very long time and improper storage condition of the eggs before setting. While, on the other hand, the very high level of egg sterility (42.6\%), relates with several factors, where the main two ones are the transport stress of the breeders, because they have just arrived from the Netherlands, the adoption stress and the temperatures stress in the new environment. The oldest eggs (20-30 days old) had the highest sterility level, which might have been embryonic mortalities as well (53\%), but at this stage it is impossible to make the difference between an early embryonic loss and a sterile egg. The hatching rate (29.9\%), compared to the total number of the set eggs is comparable with the same parameter realized in England (from 24.1 to $27.8 \%$ up to $34.9-50 \%$ according to Deeming, 1995). From the results of this study it is concluded that: the shorter the egg storage time before the setting the better the hatching results will be.
\end{abstract}

Key words: Ostrich; incubation parameters; egg weight loss; fertility; embryonic mortality

\section{ИНКУБАЦИЈА И ВЕДЕЊЕ НА ПИЛИЊА ОД ПРИПЛОДНИ ЈАЈЦА ОД НОЈ ВО ЗАВИСНОСТ ОД ВРЕМЕТО НА НИВНОТО ЧУВАҢЕ}

\footnotetext{
Истражувањето беше извршено на една фарма за ноеви во местото Патос, Албанија. Беше набљудувано едно квачење на јајцата поделени во три групи во зависност од нивната старост: јајца стари 20-30 дена, стари 10-20 дена и стари 1-10 дена. Сите 197 јајца беа означени според должината на времето на чување. За време на ведењето на пилињата беа следени, евидентирани и контролирани соодветни параметри: вкупниот број на поставените јајца, оплоденоста на јајцата, смртноста на ембрионите, губењето на маса. Во релација со овие параметри беше утврден и соодветен режим на инкубација. Просечното губење на тежината кај сите јајца, без разлика на нивната старост, беше со вредност од 5,3\%, односно 0,5\% поголемо од стандардот. Причината за високата смртност на ембрионите $(40,7 \%)$ се должи главно на многу долгото време и несоодветните услови на чување на испитуваните приплодни јајца. Од друга страна, пак, многу високото ниво на стерилитет на јајцата $(42,6 \%)$ е предизвикано од неколку фактори, од кои главни се транспортниот стрес на приплодното јато, кое беше тукушто пристигнато од Холандија, стресот при адаптација и температурниот стрес во новата средина. Најстарите јајца (20-30 дена) имаа највисоко ниво на стерилитет, што може да биде причина и за смртност на ембрионите (53\%), но во оваа фаза не е можно да се направи разлика помеѓу раната загуба на ембрионите и стерилитетот на јајцата. Стапката на ведење $(29,9 \%)$ во споредба со вкупниот број на поставените јајца е споредлива со истиот параметар добиен во Англија (од 24,1-27,8\% до 34,9-50\% според Deeming, 1995). Од резултатите од ова истражување се заклучува дека приплодните јајца чувани пократко време пред поставувањето даваат подобри резултати во ведењето.
}

Клучни зборови: ној; параметри на инкубација; загуба во маса на јајца; фертилност; ембрионална смртност 


\section{INTRODUCTION}

Ostrich production and management is still a young industry, not only in Albania but in Europe as well. South Africa is the main well-known area for the biggest number of ostrich farms, but during the recent years the interest on the ostrich farming has been increasing world wide. There are around 125 ostrich farms in the Netherlands, (Horst v. d. , 1998). Since 2005, thanks to a PSOM project, financed by the Dutch Government, it is established the ANOC (Albanian Netherlands Ostrich Company), a joint-venture between an Albanian broiler producer company and two Dutch partners. The ANOC started its activity based on a 110 breeders flock (parent stock) imported from the Netherlands in 2005, while since then the activity of the company has been gradually growing reaching at about 1000 fatteners at different ages and categories (from day-old chicks to finishers) today.

In the very beginning of the company, because the hatchers had not been brought, the first season's eggs were hatched in a rented laying hens' hatchery, which was changed in the next season to the "proper" hatchery, part of the integration.

As stated above, the ostrich farming in Albania is a quite new business and experience, and as such, we have been facing a lot of difficulties, related both with the hatching process and growing the young chicks, especially in the first days/weeks of their life.

Interesting factors in the industrial ostrich production are the artificial incubation of eggs and the rearing of chicks to an age, usually 3 months, at which the birds can be considered independent and hard (Ley et al, 1986; Shivaprasad, 1993; Deeming and Ayres, 1994; Deeming, 1995).

As far as the above statement, the following study was performed, in order to analyze and find the highest priorities and the most influential factors, effecting the commercial ostrich breeding and farming, ostrich eggs incubation, issues not yet quite clear even in other countries, because of the limited studies related to them (Deeming et al., 1993).

Because of the difficulties faced in bringing the existing hatchery into an acceptable function to hatch the first ostrich eggs in our country, and on the other hand, the limited number of available hatching eggs, we were forced to set eggs collected during a 30 days period of time.
Objective of the study: Evaluation of the artificial incubation parameters depending on ostrich eggs storage time.

Ways of realising the study:

- Monitoring the incubation cycle of ostrich eggs, during three different time frames,

- Evaluation of the incubation parameters from the first day of setting to the hatching day.

- Determination of the optimal storage time of the eggs, before the incubation process based on the outcome results.

\section{MATERIAL AND METHOD}

Monitoring and evaluation process was done in the hatchery of Patos/Albania. The hatching process technology was implemented very correctly and carefully, in the meantime the factors of the incubation physical regime were monitored and evaluated.

197 eggs (marked with an identification number and laying date) were examined through candling before having been set in the setters and egg weights were recorded. After two weeks, all eggs were weighed and candled again, in order to find the exact weight loss and the size of the air cell, as the main factors that indicate the progress of the hatching process and especially the level of the relative humidity in the hatchery. The infertile eggs were removed from the setter on day 28. During these operations, the eggs were grouped according to their age and storage time (the first group represents the 20-30 day old eggs, the second one, the 10-20 day old egg, while the third group comprised the 1-10 day old eggs). The following parameters were recorded:

1. Egg weight loss due to the evaporation

2. Number of the sterile eggs (all eggs were candled after 2 weeks).

3. Number of died embryos.

4. Number of the hatched eggs.

Results of this monitoring were statistically processed (the ANOVA and the Descriptive Analysis) and evaluated.

\section{RESULTS AND INTERPRETATION}

\section{1) Eggs weight loss}

Immediately after being laid, the egg cell starts to evaporate. The degree of the evaporation 
depends on the eggshell porosity and the relative humidity into the setter. A non-sufficient evaporation, will lead to low quality / oedematous chicks and when the weight loss is excessive the embryo dies of dehydration.
In the following tables, the egg weight at the moment of setting and two weeks after the setting moment, is displayed (as they were grouped according to their age in the storage).

Table 1.1

Eggs weight according to their age

\begin{tabular}{ccccc}
\hline \hline \multirow{2}{*}{ Parameters } & \multicolumn{4}{c}{ First weighting (at the moment of setting) } \\
\cline { 2 - 5 } & G.1 & G.2 & G.3 & Average \\
\hline M \pm SD & $1587.13 \pm 135.86$ & $1572.84 \pm 146.08$ & $1562.13 \pm 136.67$ & $1572.55 \pm 140.06$ \\
Variance & 18458.4 & 21339.3 & 18678.5 & 19615.7 \\
CV $(\%)$ & 8.6 & 9.3 & 8.7 & $\mathbf{8 . 9}$ \\
\hline \hline
\end{tabular}

Table 1.2

Eggs weight according to their age

\begin{tabular}{|ccccc|}
\hline \multirow{2}{*}{ Parameters } & \multicolumn{4}{c|}{ Second weighting (two weeks after the setting) } \\
\cline { 2 - 5 } & G.1 & G.2 & G.3 & Average \\
\hline M \pm SD & $1509.88 \pm 117.07$ & $1491.99 \pm 126.05$ & $1473.98 \pm 126.32$ & $1489.86 \pm 124.14$ \\
Variance & 13706.5 & 15888.7 & 15957.2 & 15411.5 \\
CV (\%) & 7.7 & 8.4 & 8.6 & 8.3 \\
\hline \hline
\end{tabular}

As it can easily be seen, in both weightings, although the eggs of the first group are heavier, the differences between the two groups are not significant ( $t$-test). It needs to be highlighted the fact that the storage conditions of the eggs have been poor and out of the required standards.

Now, let's have a look at the weight loss of the eggs after two weeks of incubation, referring to the above table. The differences between the two weightings are significant, both for the individual groups and for the average values. This shows the egg weight loss during the two weeks period of time (Graph 1).

All the eggs under the incubation have shown an average weight loss of $5.3 \%$, or $0.5 \%$ more than the standard norm. The higher egg weight loss is the result of several factors, such as:

- Temperature and relative humidity not kept within the required/standard parameters.

- Lack of experience and knowledge how to work with the ostrich eggs.

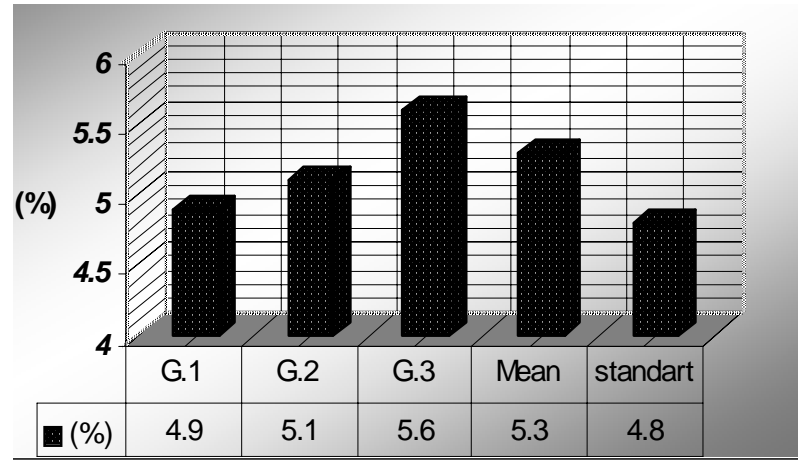

Graph 1. Egg weight after 2 weeks of incubation (\%)

Anyhow, this finding has been done only for the first two weeks of incubation.

At Table 2, one can see that after two weeks of incubation time, the air cell has been visibly increased and the differences are significant $(t-$ test). 
Table 2

Monitoring of the air cell size

\begin{tabular}{lcccccc}
\hline \hline & $\mathrm{M} \pm \mathrm{SD}$ & Variance & $\mathrm{CV}$ & Number of weighted eggs & $T_{\text {statistical }}$ & $T_{\text {critical }}$ \\
\hline Air cell: & & & & & $1: 2$ & $1: 2$ \\
1) At the moment of egg setting & $28.62 \pm 5.0$ & 25.05 & 17.5 & 28 & 28 & 16.85 \\
2) After 2 weeks incubation & $52.35 \pm 5.53$ & 36.64 & 10.6 & 2.01 \\
\hline \hline
\end{tabular}

According to Ley et al., 1986, Raines (1994), the ostrich eggs, compared to the other species' ones, need a lower relative humidity, that is why one of the bottlenecks of the incubation process of the eggs of this species is to keep the relative humidity within the required limits. Being much bigger than the eggs of the other species, the ostrich eggs have bigger evaporation; this is exactly the reason why we need to keep the relative humidity at a lower level, just to allow the evaporation from the eggs, in such a way that it can lose about 11$15 \%$ of its initial weight until the end of the incubation period. This weight loss will increase the size of the air cell, which at the end of the incubation period will be at the size of $1 / 3$ of the egg's volume. Eggs that lose less than $10 \%$ or more than $20 \%$ of their initial weight are less likely to hatch (Deeming et al., 1993, 1995).

When the weight loss is excessive, the embryo dies of dehydration (Rahn et al., 1979; Tullet, Deeming, 1992).

\section{2) Sterile eggs}

In this study, the eggs were candled four weeks after the eggs were sett, in order to find the sterile ones. The breeders were in the first reproduction season (the females 3 year old, while the males were 4 year old) and the male : female ratio was $3 q: 1{ }^{\lambda}$.

Higher sterility (39.6\%) relates with the high temperature in the farm.

According to Blessing D. (1998), because of the handling stress (transportation, moving from one house to another one) and/or the high environmental temperatures, the insemination might not be effective. According to the different sources of literature, infertility rate varies widely, from $22.2 \%$ in the United Kingdom to $42 \%$ in America (Hicks, 1993; Deeming, 1995).
As it can clearly be seen in the Graph 2, the sterility is higher in the group 1, where the eggs were stored for a 20-30 day period of time. According to Nahm K. H (2001), the rate of infertility for the eggs stored for 19 days was $20 \%$.

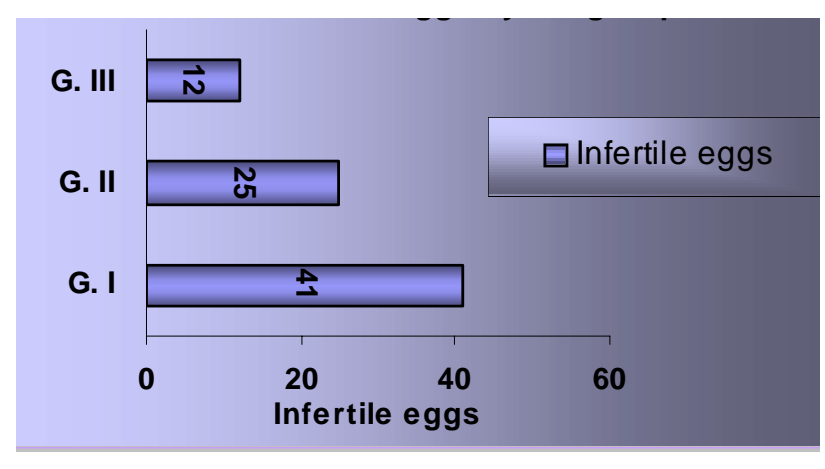

Graph 2: Number of infertile eggs by the groups

\section{3) Embryonic mortality}

During this study, a high rate of embryonic mortality was evidenced, using two parameters as reference: Embryonic mortality referring to the total number of fertile eggs, which is in the level of $40.7 \%$ of the fertile eggs, and the embryonic mortality in comparison with the total number of the sett eggs, which is in the level of $23.4 \%$.

According to Nahm K. H. (2001), these parameters were respectively $20.8 \%$ and $16.7 \%$. Long term storage of eggs before the sett resulted to early embryonic mortality, which can be evidenced through the second and/or the third candling process.

Embryonic mortality can be categorized as follows: early embryonic mortality (the first peak at the 7 days), mid embryonic mortality; late embryonic mortality at the advanced embryonic development phase (the second peak at the 4-5 last days) and dead in shell (at time of hatching) (Madeiros, 1996). 
Early embryonic mortality has been associated with delayed egg collection, too high storage temperature, infected eggs, while mid embryonic mortality has been associated with inadequate egg turning and rough egg handling. (Blessing D. et al., 1998). Late embryonic mortality is related to inadequate ventilation and fluctuating incubation temperature, too high hatchery humidity and malpositions of the head (Stewart, 1993).

\section{4) Hatched eggs}

As it can be seen in the above presented graph, the hatching rate of the eggs is relatively low, but anyhow comparable with the same parameters in some countries where the ostrich is grown, such as the United Kingdom, where it is reported that the hatchability rate in comparison with the sett eggs, fluctuates between $24.1-27.8 \%$ up to $34.9-50 \%$ (Deeming, 1995).

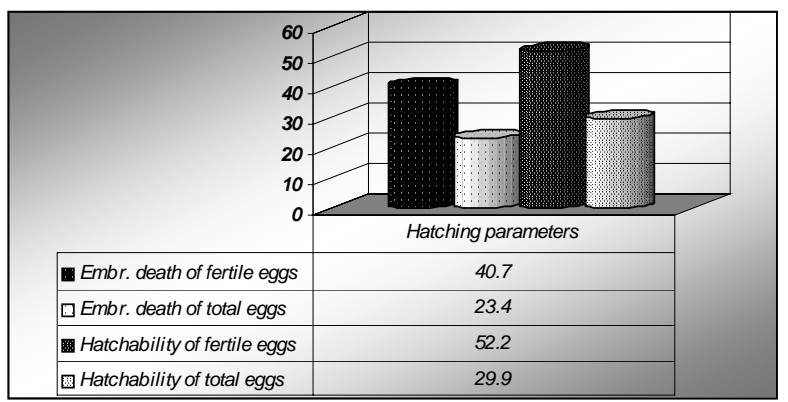

Graph 3: Hatching parameters of ostrich eggs (\%)

In our study, it has been concluded that the low rate of hatchability relates with the problems within the incubation process (high rates of infertility and high embryonic mortality). Previous reports (Meyerhof, 1992) have indicated that high rates of infertility, a very long storage period without appropriate conditions contribute to lower hatchability.

As it was stated in the beginning, the first eggs were hatched in an existing incubator which was previously used to hatch hens' eggs. This incubator was very big for the limited number of eggs we put in it; consequently, it was very difficult to meet the necessary microclimatic parameters within it. According to Dijkman Else, 1996, within the incubator's space there might be created both "hot" and/or "cold" spots, which in both cases have a negative influence on the hatchability of the eggs.
A high relative humidity should be maintained of $50-75 \%$ and eggs should not be stored longer than 7-10 days, because it will reduce hatchability (Wilson, 1997). It is found however that eggs having been stored for longer periods show the same hatchability, but much lower chick survival (Badley, 1997).

Environmental conditions influence ostrich egg hatchability, including the length of the storage period, temperature, humidity, gaseous, environment and orientation of the eggs (Meyerhof, 1992; Mellett, 1993). Eggs storage related to the $\mathrm{pH}$ of the albumen due to the loss of Carbone Dioxide (Dawes, 1975), which is important in maintaining embryonic viability results in a decreased hatchability (Kirks et al., 1980).

So, according to the above mentioned logic, facts and arguments, it can be stated that: The shorter the storage time of the eggs, the better the hatching result of them will be.

\section{CONCLUSIONS:}

1. The high evaporation rate from the eggs $(0.5 \%$ higher than the norm) was caused because of both improper microclimatic parameters in the incubator and lack of experience/know how related to the ostrich eggs handling and incubation process.

2. High environmental temperatures in the breeders' farm have influenced an increased sterility rate $(39.6 \%)$.

3. Storage of the hatching eggs for a longer period of time has led to an early embryonic mortality during this sett. While the low hatching percentage mostly relates with the problems during the incubation process.

\section{REFERENCES}

[1] Badley A. R. (1997): Fertility, hatchability and incubation of ostrich eggs. Poultry and avian biology. 8, 53-76.

[2] Blessing D. (1998): Veterinary problems of the ostrich (Struthio Camelus) up to 12 weeks of age.

[3] Dawes C. M. (1975): Acid - Base relationships within the avian egg. Biological Rev. 50, 351-371.

[4] Deeming and Ayres (1994): Factors affecting the rate of growth of ostrich chicks in captivity. The Veterinary Record, 135, 617-622. 
[5] Deeming et al. (1993): Observation of the commercial production of ostrich in the UK. The Veterinary Record, 132, 627-631.

[6] Deeming D. C. (1995): Factors affecting hatchability during commercial incubation of ostrich (Struthio camelus) eggs. British Poultry Science, 36, 51-65.

[7] Dijkman E. (1996): Survey on incubation problems and chick mortality in Zimbabwe.

[8] Dzoma Blessing M.. Hage Mareinv D. (1998): Ostrich chick production: Veterinary problems, pathology and productivity.

[9] Hicks (1993): Ostrich reproduction. In: M. E Fowler (Ed), Zoo and Wild Animal Medicine, Current Therapy 3; 203206.

[10] Horst V. D. F. (1998): The European Ostrich Association' Netherlands representative.

[11] Kirks S., Emmans G. C. et al. (1980): Factors affecting the hatchability of eggs from broiler breeders. British Poultry Sci. 21, 37-53.

[12] Ley et al. (1986): Mortality of chicks and decreased fertility and hatchability of eggs from a captive breeding pair of ostriches. Journal of the American Veterinary Medical Association, 189, 556-563.

[13] Madeiros (1996): Incubation trouble shooting - causes of poor incubation/hatching results. Conference at Hengelo, Netherlands.
[14] Mellett F. D. (1993): Ostrich production and products. 187-194, Livestock Production systems; Principles and Practice.

[15] Meyerhof R. (1992): Pre-incubation holding of hatching eggs. World's Poultry Sci. J., 48, 57-68.

[16] Nahm K. H. (2001): Effects of storage and weight loss during incubation on the hatchability of ostrich eggs (Struthio Camelus).

[17] Rahn et al. (1979): How the bird eggs breathe. Scientific American, 240, 46.

[18] Raines, A. M. (1994): How to evaluate a ratite facility to aid in diagnosing chick mortality. Proceedings of the Association of Avian Veterinarians. Main Conference: Ratites.

[19] Stewart (1993): Hatcher management in ostrich production. In M.E Fowler (Ed), Zoo and Wild Animal Medicine, Current Therapy 3, 206-211.

[20] Tullet Deeming (1992): The relationship between eggshell porosity and oxygen consumption of the embryo in the domestic fowl. Comparative Biochemistry and Physiology, 72;

[21] Wilson H. R. et al. (1997): Storage time and ostrich egg hatchability. Journal of Applied Poultry Research. 6 (2) 216-220. 